\title{
Stigmatization of People Living with HIV in Medan: A Qualitative Study
}

\author{
Eva Kartika Hasibuan ${ }^{1 *}$, Novita Aryani $^{2}$, Jek Amidos Pardede ${ }^{3}$, Galvani Volta Simanjuntak ${ }^{2}$
}

${ }^{1}$ Department of Community Nursing, Sari Mutiara Indonesia University, Medan, Indonesia

${ }^{2}$ Departement of Medical Surgical Nursing, Sari Mutiara Indonesia University, Medan, Indonesia

${ }^{3}$ Departement of Mental Health Nursing, Sari Mutiara Indonesia University, Medan Indonesia

\author{
DOI: $10.36348 /$ sjnhc.2020.v03i05.001 \\ | Received: 04.05.2020 | Accepted: 24.05.2020 | Published: 30.05.2020 \\ *Corresponding author: Eva Kartika Hasibuan
}

\section{Abstract}

HIV-related stigma is a psychological challenge in People Living With HIV (PLWH). They have different personal experiences related to the stigma. This study aims to explore personal experiences of PLWH related to HIV stigma. This study is a qualitative study with phenomenological design which was conducted to PLWH in Medan City in the period of Mei 2019. The data were collected through in depth interview and analyzed by performing trial version of Nvivo. Ethical test and inform consent were granted prior to data collection. There were 4 participants in the study and $75 \%$ of the respondents were male and $75 \%$ of which held higher education degree. It was obtained that the average length of being HIV positive was 2.3 years. Thematic analyses reveable three common stigma received by PLWH: (1) interpersonal stigma (feeling of being stigmatized, Rejected and considered as a disgusting creature), (2) stigma at health facilities (Discriminating look, Verbal abuse, and Delayed service due to their HIV positive status), and (3) self stigma (Avoidance in using the same things with the participants, Delayed service due to their HIV positive status). Findings provide important insights related to design of interventions to reduce stigmatization of PLWH.

Keywords: People living with HIV, Patient Experiences; Stigmatization; Medan.

Copyright @ 2020: This is an open-access article distributed under the terms of the Creative Commons Attribution license which permits unrestricted use, distribution, and reproduction in any medium for non-commercial use (NonCommercial, or CC-BY-NC) provided the original author and source are credited.

\section{INTRODUCTION}

People living with HIV (PLWH) are disadvantaged from complex issues; not only physical problems due to their health condition, but also psychosocial problems such as stigma and discrimination [1, 2]. HIV related stigma occurs because of negative attitudes from people in the society toward the behavior of PLWH which are considered to be distorted from the social norms. They are labeled as "immoral" "screwed up" "misguided" [3]. Consequently, the stigma may isolate PLWH from the society and lead to a host of negative impacts, including their adherence to medication $[4,2]$. They might reduce their willingness to seek help and support, delay or even terminate their medical treatment [5]. Health profile from the Ministry of Health of the Repulic of Indonesia about the current situation of HIV/AIDS in Indonesia estimates that there are 640.443 people living with HIV, but, by December 2019, there were only 377.564 people were aware of their HIV positive status. From the overall PLWH who know their health status, $72 \%$ of those are reported to have undertaken ARV medication, while only $47 \%$ regularly receive ARV treatment [6].
Indonesian government has carried out fast tract as a way of HIV prevention with $90 \%$ of treatment target [6]. There are over 5000 locations of HIV test administration and 600 locations for medical treatment. However, this strategy is yet adequate to anticipate stigma from the society toward PLWH leading to PLWH reluctance to seek medication at health facilities[6]. The high level of HIV/AIDS related stigma and discrimination in Indonesia makes PLWH reluctant to undergo medical treatment and regular check-up [5]. As the level of stigmatization in society is still high, combating stigma related to HIV has been one of the biggest concerns of global community [7]. It is because the stigma has been a primary barrier to the success of HIV transmission prevention and HIV treatment adherence $[8,4]$. Therefore, this condition intrigues the authors to identify kinds of stigma that are commonly experienced by PLWH in Indonesia.

\section{MATERIAL AND METHODS}

The descriptive phenomenological design was employed in this study to identify stigma related to HIV experienced by PLWH. The research subjects were people living with HIV/AIDS in Medan. The samples were selected through snowball sampling technique. 
The data were collected by performing in-depth interview conducted by the researcher with the duration of the interview was 40-60 minutes. Before the data collection, the study had granted an approval from the Research Ethics Committee of Faculty of Medicine of University of Muhammadiyah Sumatera Utara with certificate number 254/KEPK/FKUMSU/2019. Research objectives and procedures were informed to the respondents. All respondents in this research were asked to sign an informed consent form. Respondents' rights were protected and all respondents participating in the study did not receive any kinds of pressure from any parties. The respondents had full authority to cancel their participation in this study. Respondents' names were indicated through initials to protect confidentiality. The data in this study were collected from 4 respondents. Member check was carried out over the transcript to match the factual information from the respondents. Data were collected within the period of May 2019. Upon the completion of data collection, the data were analyzed to identify keywords, subthemes, and themes. The data analyzed by a trial version of Nvivo 12.0.

\section{RESULTS}

The age range of the participants in the present study was 21-32 years old, that the average length of being HIV positive was 2.3 years, $75 \%$ of the participants were male and mostly held high level of education background (75\%). This study found 3 major themes of stigma, namely interpersonal stigma, stigma in health care facilities, and self stigma.

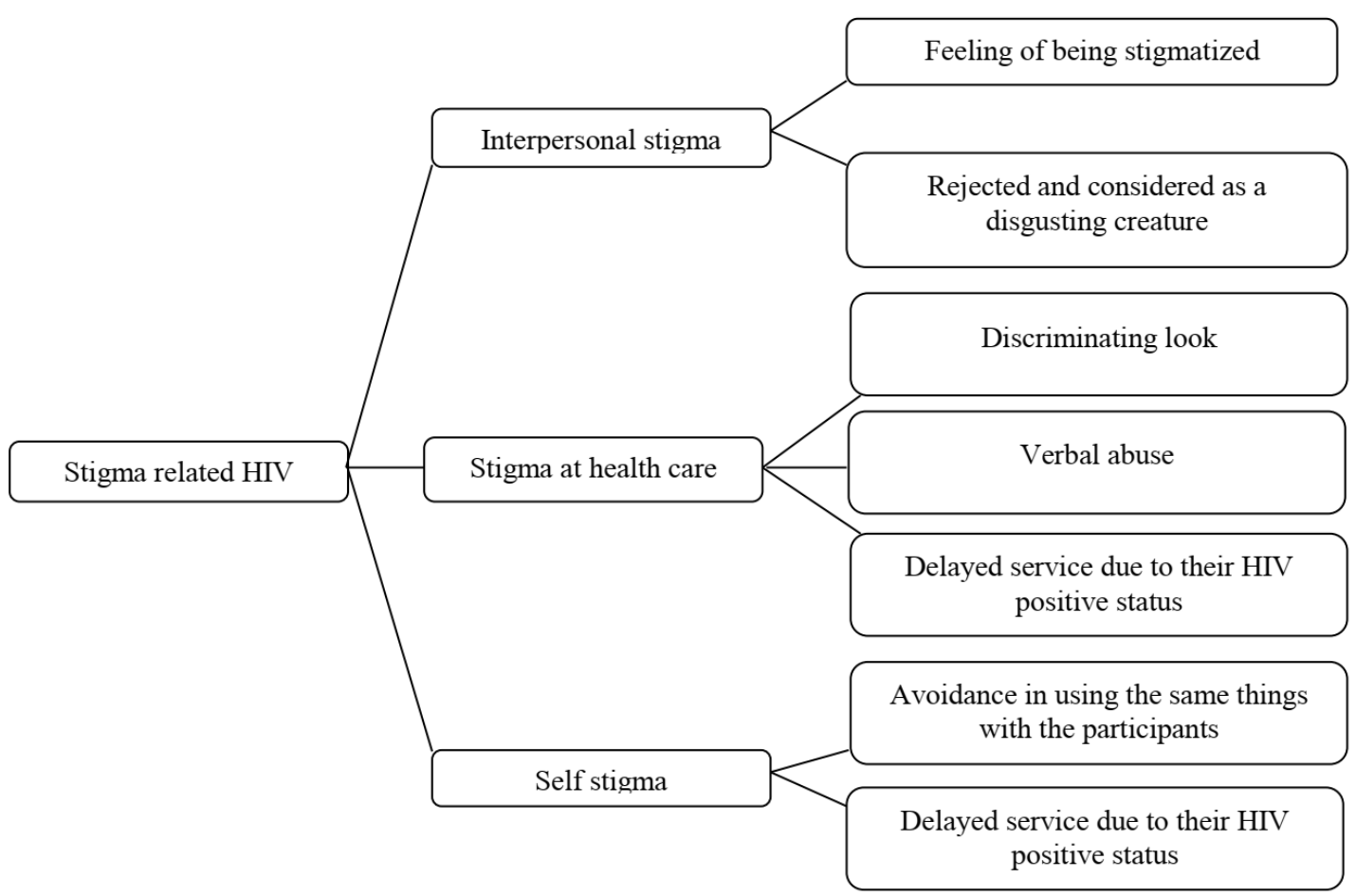

Fig-1: Stigma related HIV Experiences

The respondents reported to have experienced interpersonal stigma such as rejection from their family members and friends and avoidance in using the same things with the participants.

"Finally, I talked to my brother and I decided to be honest. There were only me, my sister who has been married, my little sister and my mom. No other family members know about it. After a very long story, their reaction was only silence and they asked me to do this and that. Shortly, they went back to their home and since then they started to keep a distance from me. Then, my sister told about my condition to other family members and that was the main reason of our family disputes. She probably shared my story to get a solution, but what I get is only discrimination, rejection, and I feel like they want me to be away as far as possible". (Participant 3)

"My close friend starts to keep a distance from me, they even do not want to touch my computer mouse when we are working together". (Participant 4)

Stigma at health care facilities includes discriminating look, verbal abuse, and delayed service due to their HIV positive status.

"I experienced stigmatization and discrimination at a clinic when I was taking my medical referral letter. I remember that stared at me with discriminating look." (Participant 1) 
"Then, I felt like they delayed providing me the referral letter because they that I am a patient with HIV/AIDS." (Participant 1)

"I've ever received different treatment from health personnel. At first, I was asked to take a medical referral letter from the public health center. Back then, I did not put on face mask every time I processed the medical referral letter. But then, after knowing my health status, I felt like, each of them kept staring at me with a strange look." (Participant 2)

"So, back when I was at a public health center, it happened that one of them said, 'see, that person is HIV infected." (Participant 2)

"Then, the health personnel said, 'that's impossible, you are HIV infected. That's impossible!' That health personnel said it quite loud, and made other people around us looked at us". (Participant 3)

Moreover, the self stigma reported by the participants includes feeling of being stigmatized, rejected and considered as a disgusting creature.

"Oh yes, I personally feel rather uncomfortable because sometimes I use gloves, I use these, I feel like I am rejected and neglected, like something disgusting". (Participant 1)

"I don't want to go anywhere and stay at home. I don't want to meet anyone. I have a very poor self-esteem and a feeling of being rejected". (Participant 2)

"At that time, they regarded me like rubbish (laughing). Sometimes, I think this disease is a disgusting disease, like trash, so sometimes, it makes me feel like there is something disgusting in me". (Participant 3)

"I am not sure if it is from blood transfusion or because of my own behavior. I have ever received blood donation; 17 bags from the Red Cross. However, people thought that I have done negative moral behaviors". (Participant 4)

\section{DISCUSSION}

HIV-related stigma brings negative effects on the treatment and medication of the patients, which eventually affect patients' health mentally and physically as well as the quality of life of the patients $[9,10]$. Stigma occurs from exaggerated prejudice and fear related to HIV. As the result, PLWH may be humiliated, rejected, and neglected by the family, close friends, and society. In addition, the interpersonal stigma results in PLWH's reluctance to reveal their HIV positive status to their family or close friends despite the fact that they have known their health status for a long period of time. Apparently, PLWH who tell their health status to their family or close friends receive judgment and rejection instead of support. It might be a result of the negative perception that having a family member or friend with HIV/AIDS is a disgrace leading to bad social relationship and family dignity in the society [11]. Therefore, there are many PLWH hide their HIV positive status. By keeping the health status in secret, they feel more safe living their daily life.

Ideally, family members, close friends, and health personnel at health care facilities are important people from whom PLWH gets support and reliable information about their disease. However, in many cases, stigmatization and discrimination come from those people. A study about the stigmatization of health personnel at health care facilities in Aceh and Bandung reported that health personnel are likely to have high levels of stigma over PLWH [12, 13]. PLWH received verbal insult from health personnel by mentioning their HIV positive status with a loud voice, looking at the patients with cynical stare because they perceive PLWH as bad and disgusting person due to their misguided behavior [14]. HIV antibody tests without consent, differential treatment, disclosed information and refused to treat and care, breaches of confidentiality, refusal to operate or assist in clinical procedures; cessation of ongoing treatment; early discharge from hospital; judgemental attitudes of hospital workers; physical isolation in the ward; restrictions on movement around the ward or room; restricted access to shared facilities; denial of hospice facilities; refusal to lift or touch the dead body of an HIV-positive person; and reluctance to provide transport for the dead body of an HIV-positive person merupakan bentuk stigma dan diskriminasi yang sering dilakukan petugas kesehatan $[15,16]$. PLWH receive negative treatment from health personnel because of their irrational fear that the transmission might happen during direct contact with the patient [17].

PLWHs experiencing stigma in their daily life incline to grow self stigma in them [18]. Negative perceptions received from the society are adopted and in some degree affect how PLWH seeing negative selfconcept in them [8]. It is likely that they blame themselves, lack of self-esteem, lose motivation, do not want to interact with other people. Other kinds of self stigma faced by PLWH include fear of being abandoned by their spouse/ family/ friend. Besides, they are also afraid that their HIV positive status might be revealed when they take ARV at health centers [19]. It is reported that self-sigma may bring more negative effects that other kinds of stigma [9]. self stigma is known to cause bigger negative impacts on PLWH's mental health, such as anxiety, depression, psychological and emotional disorders, and lower quality of life [10]. 
Despite the fact that the level of knowledge of Indonesian people about HIV is relatively high, the level of HIV related stigma is still high [20]. People in the society are still holding strong stigma and discrimination toward HIV related cases, regarding this issue from social and ethical point of view. One factor that might be associated with this issue is probably eastern values and norms in the society. Most of the people in Indonesia perceive that people with HIV have negative behaviors which are against the norms and values in society. They think that PLWH are people who do bad deeds such as sex workers, drug addicted, and people with sexual disorientation. Besides, they also consider PLWH as a person who brings disgrace to the family. In other words, stigma related to HIV is still a big issue in Indonesia.

\section{CONCLUSIONS}

Stigma is still a fearful issue among PLWH. Stigma experienced by PLWH includes interpersonal stigma, stigma at health care facilities, and self stigma. Findings provide important insights related to design of interventions to reduce stigmatization of PLWH.

\section{ACKNOWLEDGEMENTS}

We would like to thank Ministry of Research, Technology and Higher Education Republic of Indonesia for funding this research. We also thanks to Medan Plus Foundation for collect data processing support.

Conflict of Interest: The authors declare that they have no conflict of interest.

\section{ETHICAL APPROVAL}

The study was approved by the Research Ethics Committee of Faculty of Medicine of University of Muhammadiyah Sumatera Utara and certify that the study was performed in accordance with the ethical standards as laid down in the 1964 Declaration of Helsinki and its later amendments or comparable ethical standards (certificate number 254/KEPK/FKUMSU/2019).

\section{REFERENCES}

1. Dejman, M., Ardakani, H. M., Malekafzali, B., Moradi, G., Gouya, M. M., Shushtari, Z. J., ... \& Mohraz, M. (2015). Psychological, social, and familial problems of people living with HIV/AIDS in Iran: A qualitative study. International journal of preventive medicine, 6(1):126-136.

2. Dahlui, M., Nazar Azahar, A. B., Zaki, R., Oche, O. M., Adekunjo, F. O., \& Chinna, K. (2015). HIV/AIDS related stigma and discrimination against PLWHA in Nigerian population. PloS one, 10(12).

3. Addo-Atuah, J., \& Lundmark, W. (2015). Book Review: Stigma, Discrimination, and Living with
HIV/AIDS:

A

Cross-Cultural

Perspective. Frontiers in public health, 3, 242.

4. Li, Z., Morano, J. P., Khoshnood, K., Hsieh, E., \& Sheng, Y. (2018). HIV-related stigma among people living with HIV/AIDS in rural Central China. BMC health services research, 18(1), 453.

5. Shaluhiyah, Z., Musthofa, S. B., \& Widjanarko, B. (2015). Stigma masyarakat terhadap orang dengan HIV/AIDS. Kesmas: National Public Health Journal, 9(4), 333-339.

6. Ministry of health of the republic of Indonesia, 'The Report of the situation of HIV / AIDS and PIMS in Indonesia January-December 2019'. Ministry of health of the republic of Indonesia, Feb. 17, 2020, Accessed: Feb. 10, 2020. [Online]. Available:

https://siha.kemkes.go.id/portal/files_upload/Lapor an_Perkembangan_HIV_AIDS PIMS_TRIWU LAN_IV_TAHUN_2019.pdf.

7. UNAIDS, '90-90-90 An ambitious treatment target to help end the AIDS epidemic'. UNAIDS, Oktober 2014, Accessed: Feb. 20, 2020. [Online]. Available:

https://www.unaids.org/sites/default/files/media_a sset/90-90-90_en.pdf.

8. Subedi, B., Timilsina, B. D., \& Tamrakar, N. (2019). Perceived stigma among people living with HIV/AIDS in Pokhara, Nepal. HIV/AIDS (Auckland, NZ), 11, 93-103.

9. Phillips, K. D., Moneyham, L., \& Tavakoli, A. (2011). Development of an instrument to measure internalized stigma in those with HIV/AIDS. Issues in Mental Health Nursing, 32(6), 359-366.

10. Chambers, L. A., Rueda, S., Baker, D. N., Wilson, M. G., Deutsch, R., Raeifar, E., \& Rourke, S. B. (2015). Stigma, HIV and health: a qualitative synthesis. BMC Public Health, 15(1), 848.

11. Boushab, B. M., Fall-Malick, F. Z., Melaïnine, M. L. O. C., \& Basco, L. K. (2017). Forms of stigma and discrimination in the daily lives of HIVpositive individuals in Mauritania. The open AIDS journal, 11, 12-17.

12. Wilandika, A. (2019). Health Care Provider Stigma on People Living with HIV/AIDS (PLWHA) in Bandung. Jurnal Keperawatan, 10(1), 7-15.

13. Sofia, R. (2018). Stigma and Discrimination against Aids (Studies in Health Workers In The Tanah Pasir Health Center Of North Aceh). Jurnal Kedokteran dan Kesehatan Malikussaleh, 2(1):7989.

14. Maharani, R. (2014). Stigma dan Diskriminasi Orang Dengan HIV/AIDS (ODHA) pada Pelayanan Kesehatan di Kota Pekanbaru Tahun 2014. Jurnal Kesehatan Komunitas, 2(5), 225-232.

15. Dong, X., Yang, J., Peng, L., Pang, M., Zhang, J., Zhang, Z., ... \& Chen, X. (2018). HIV-related stigma and discrimination amongst healthcare 
providers in Guangzhou, China. BMC public health, 18(1), 738 .

16. Hossain, M. B., \& Kippax, S. (2011). Stigmatized attitudes toward people living with HIV in Bangladesh: health care workers' perspectives. Asia Pacific Journal of Public Health, 23(2), 171-182.

17. Ardani, I., \& Handayani, S. (2017). Stigma terhadap Orang dengan HIV/AIDS (ODHA) sebagai Hambatan Pencarian Pengobatan: Studi Kasus pada Pecandu Narkoba Suntik di Jakarta. Buletin Penelitian Kesehatan, 45(2), 8188.

18. Turan, B., Hatcher, A. M., Weiser, S. D., Johnson, M. O., Rice, W. S., \& Turan, J. M. (2017). Framing mechanisms linking HIV-related stigma, adherence to treatment, and health outcomes. American Journal of Public

Health, 107(6), 863-869.

19. Helms, C. B., Turan, J. M., Atkins, G., Kempf, M C., Clay, O. J., Raper, J. L., ... \& Turan, B. (2017). Interpersonal mechanisms contributing to the association between HIV-related internalized stigma and medication adherence. AIDS and Behavior, 21(1), 238-247.

20. Ministry of health of the republic of Indonesia, Laporan Nasional RISKESDAS 2018 (The 2018 basic health research report)'. Ministry of health of the republic of Indonesia, 2019, Accessed: Feb. 10, 2020. [Online]. Available: http://labdata.litbang.kemkes.go.id/images/downlo ad/laporan/RKD/2018/Laporan_Nasional_RKD20 18_FINAL.pdf. 